\title{
Az indirekt beszédaktusok feldolgozásának reakcióidő-méréses vizsgálata
}

Jagodics Balázs ${ }^{1}$, Janacsek Karolina ${ }^{2}$, Németh Dezső ${ }^{2}$

${ }^{1}$ Pszichológiai Intézet, Szegedi Tudományegyetem

${ }^{2}$ Klinikai Pszichológia és Addiktológia Tanszék, Pszichológiai Intézet, Eötvös Loránd Tudományegyetem

Levelezési cím:

Németh Dezső

Klinikai Pszichológia és Addiktológia Tanszék

Pszichológiai Intézet

Eötvös Loránd Tudományegyetem

Izabella utca 46.

1064, Budapest

Email: nemethd@gmail.com 


\section{Összefoglaló}

Mindennapi nyelvhasználatunk során gyakran fejezzük ki szándékainkat indirekt módon. A nem szó szerinti jelentéstartalmon keresztül folytatott kommunikáció kutatása hosszú múltra tekint vissza mind a jelenség nyelvészeti hátterét, mind pedig a beszédforma pszichológiai megközelítését tekintve. Ez utóbbi tudományterület a korábbiakban elsősorban az indirekt beszédaktusok használata mögött húzódó stratégiai okokra és logikai magyarázatokra koncentrált. Jelen kutatás egy új aspektusból járja körül a kérdéskört: a kognitív feldolgozás felöl. A fő kérdésünk, hogy vajon a direkt és az indirekt mondatok feldolgozásának idői mintázatában van-e különbség? Tovább árnyalva a képet megvizsgáljuk, hogy vajon az általános és társas kognitív funkciók, mint a munkamemória és a mentális állapot tulajdonítás meghatározza-e -és ha igen, hogyan- a rejtett tartalommal bíró mondatok használatát. A mondatok feldolgozását önütemezett olvasási helyzetben mértük, ahol a függő változó a feldolgozási idő volt. A munkamemória kapacitást a hallási és a számlálási terjedelem tesztekkel, míg a mentális állapot tulajdonítást a Faux Pas teszttel mértük. Az eredményeink azt mutatják, hogy a direkt mondatok feldolgozása gyorsabb mint az indirekt mondatoké. A tanulmány eredményei szerint különbséget találhatunk a magas- és az alacsonyabb munkamemória kapacitású személyek mondatfeldolgozásának mintázatában. Az elmeteória fejlettség viszont nem befolyásolta az indirekt megnyilatkozások feldolgozásának sebességét. Összefoglalva, annak ellenére, hogy a hétköznapi életben gyakran használjuk az indirekt megfogalmazást, a kognitív feldolgozás szempontjából mégis kapacitás -igényesebb.

Kulcsszavak: indirekt beszédaktus, reakcióidő, mentális állapottulajdonítás, munkamemória, nyelvi feldolgozás 
A hétköznapi nyelvhasználat során gyakran fejezzük ki magunkat indirekt megnyilatkozásokkal ahelyett, hogy nyílt megfogalmazású beszédaktusokkal közölnénk a gondolatainkat. Ilyen esetekben előfordul, hogy szándékainkat homályos, burkolt kifejezésekkel igyekszünk a kommunikációs partner tudomására hozni. Elsősorban azokban a helyzetekben figyelhetjük meg ezt a jelenséget, amikor udvarias kérések, leplezett megvesztegetések, rejtett fenyegetések (pl. „Szép autód van. Milyen kár lenne érte, ha valami baja esne.”), mérsékelt utasítások, vagy titkolt szexuális utalások kerülnek szóba (Pinker, Nowak, \& Lee, 2008). Jelen tanulmányban először röviden tárgyaljuk azokat az elméleteket, amelyek az indirekt kijelentések pragmatikai hátterét és használatuk előnyeit magyarázzák. Ezt követően pedig egy hiánypótló empirikus kutatást mutatunk be, amelyben az indirekt kijelentések online feldolgozásának idői jellemzőit vizsgáljuk pszicholingvisztikai szempontból. A kutatásban kitérünk arra is, hogy a szándéktulajdonítási képességben illetve a munkamemória kapacitásban megjelenő egyéni különbségek hogyan befolyásolják az indirekt beszédaktusok feldolgozását.

\section{A beszédaktusok fö fajtái}

A közvetett vagy indirekt megfogalmazású beszédaktusok leírásával több nyelvészeti elmélet is foglalkozik. Austin (1962) teóriája szerint a beszéd megnyilatkozásai performatívumok (performatív mondatok vagy megnyilatkozások), vagyis az állítások önmagukban is cselekvéssel érnek fel. Igaz ez akkor is, ha a beszédaktus tartalma egy egyszerü megállapítás (konstatívum), hiszen ekkor az állítás maga az elvégzett cselekvés. Tehát a beszédaktus elmélet szerint a nyelvhasználat nem cselekvésirányító szerepben jelenik meg az emberi kommunikáció során, hanem magában is viselkedésértékü magatartásnak tekinthető (Pléh, 2012).

Searle elméletében (1975) már árnyaltabban jelennek meg a performatívumok fajtái: azok illokúciós erejük, tehát értelmük és céljuk szerint kerülhetnek öt beszédaktus-típus valamelyikébe. A teória kitér a közvetett beszédaktusok tárgyalására is, melyeket olyan megnyilatkozásokként definiál, amelyek két illokúciós erővel bírnak. Az elsődleges a beszélő szándékolt jelentése, a másodlagos pedig a beszédaktus szó szerinti jelentése. Ha a szó szerinti jelentés nem illik a kontextusba, emiatt értelmetlenként hat, a beszédpartner képes kikövetkeztetni, hogy a beszédaktus elsődleges illokúciója valamilyen mögöttes tartalom. Searle a közvetett beszédaktusokat két csoportra különítette el: a konvencionálisan közvetett beszédaktusok jelensége széleskörüen elterjedt, az udvarias kérés esetében pedig olyan nyelvi formáról van szó, amely a köznyelv kifejezéseibe is beépült szerkezetekben is megfigyelhető 
(Searle, 1975; Brown \& Levinson, 1987). A kutatások szerint ezen kifejezések közös jellemzője, hogy a nyelvhasználók széles köre képes értelmezni azokat, méghozzá nem a szó szerinti, hanem az illukóciós szempontból elsődleges jelentéstartalom alapján (Holtgraves, 1994; Gibbs, 1983). Ezzel szemben az úgynevezett „nem konvencionálisan indirekt beszédaktusok" mondanivalója csak egy bizonyos szituációban értelmezhető és az esetek nagyrészében csak a jelenlévők számára egyértelmü (Searle, 1975; Lee \& Pinker, 2010). Az ilyen kifejezések közé tartoznak többek között a fenyegetések és a szexuális csábítások bizonyos változatai, melyek megfogalmazását és megértését nagyban a szituáció, a kontextus és a közös ismeretek határozzák meg (Lee \& Pinker, 2010).

A közvetett beszédaktusok, azon belül pedig elsősorban a nem konvencionális közvetett beszédaktusok jelenségének vizsgálata amiatt válhat a tudományos érdeklődés tárgyává, hogy ez a fajta kommunikáció a beszéd eredeti funkcióját és szabályait megszegni látszik (lásd grice-i maximák; Grice, 1957): nem egyértelmü, ennélfogva könnyü félreérteni, például ha a hallgató csak a mondat szó szerinti jelentését értelmezi (Pinker, Nowak \& Lee, 2008). Grice (1975) későbbi elméletében az implikatúra kifejezést használja az olyan beszédaktusok leírására, ahol a beszélő valójában több információt oszt meg a szavainak szó szerinti jelentésénél. Az implikatúra-elmélet szerint azokban az esetekben, amikor a beszélő által megosztott információ nem elégséges, vagy a megfogalmazás homályos, a hallgató inkább a szó szerinti jelentésen túli mondanivaló létezésére fog gyanakodni, nem pedig arra, hogy a beszélő megszegi a kommunikáció együttmüködési elvét.

Jelen tanulmány a Searle-féle konvencionális - nem konvencionális elkülönítést alkalmazza az indirekt beszédaktusok tárgyalása során. Grice implikatúra-elméletét figyelembe véve pedig célunk, hogy azon megnyilatkozások feldolgozását vizsgáljuk, ahol a hallgató implikatúrával találkozik.

\section{Az indirekt beszédaktusok használatának elönyei}

Milyen előnyök okozhatják az indirekt kifejezések használatának preferenciáját? A kommunikáció során a beszélö célja nem csupán információ átadása lehet, ahogy azt Grice (1957) elmélete felvázolja. Az evolúciós teóriák szerint az emberek célja különbözhet, így az interakció célja a konfliktusok rendezése is lehet (Dawkins \& Krebbs, 1978; Williams, 1966; Trivers, 1985). Az ilyen szituációkban pedig a saját szándék érvényesítése kerül előtérbe, ami a többi ember manipulálására tett erőfeszítéseken keresztül teret enged a rejtett jelentéstartalommal bíró, indirekt megfogalmazású kifejezéseknek (lásd pl. a „stratégiai beszélö" elmélete, Pinker et al., 2008). Az indirekt megfogalmazás lehetővé teszi az 
„elfogadható tagadhatóságot” (plausible deniability), vagyis annak lehetőségét, hogy az elhangzott szöveg nem szó szerinti jelentéstartalmát a későbbiekben letagadjuk, ha a beszédpartner nem bizonyul együttmüködőnek. Az indirekt kifejezések által a kommunikációs felek „,homlokzata” (komfortja, autoritása, a self képe) védve marad egy ilyen interakció során (Goffman, 1967; Brown \& Levinson, 1987). Az indirekt beszéd elméleteiről részletesebb áttekintést nyújt Jagodics és Németh (2012).

\section{A mentális állapottulajdonitás szerepe az indirekt beszédaktusok megértésében}

A grice-i modell a kommunikációs folyamat leírása során a szándéktulajdonításra helyezi a hangsúlyt, mivel ha az emberek nem lennének képesek szándékot tulajdonítani a többi személynek, akkor lehetetlenné válna a viccek és az irónia értelmezése - valamint az indirekt kifejezések egyike sem lenne használható.

A mentális állapottulajdonitási képesség, vagy más néven elmeteória/mentalizációs képesség a többi ember szándékainak, motivációjának és érzéseinek megértésére, valamint a cselekvések bejóslására való képességet jelenti, mely a csoportos élettérben adaptív adottságnak számít (Brüne \& Brüne-Cohrs, 2006). Fejlődéslélektani vizsgálatok szerint a gyerekek három-négy éves koruk körül lesznek képesek arra, hogy a saját, illetve mások vélekedését, gondolatait elkülönítsék egymástól (Wimmer \& Perner, 1983; Perner \& Wimmer, 1985), de a más emberek mentális állapotának érzékelésére utaló jelek már 7 hónapos korban is megjelennek (Kovács, Téglás, \& Endress, 2010). A gyerekeknél 9 és 11 éves kor között jelenik meg a „faux pas” (magyarul „ballépés”, „elvétés”) helyzetek megértésének képessége (Baron-Cohen, O’Riordan, Stone, Jones, \& Plaisted, 1999). Ezekben a szituációkban valaki olyan dolgot mond, amit nem kellett volna, mert a „faux pas”-t tartalmazó megnyilvánulással megbántott vagy kínos helyzetbe hozott valakit. Ez jellemzően oly módon történik, hogy a „ballépés” nem tünik fel a beszélőnek azonnal, általában valamilyen elözetes információ hiánya miatt (például egy kiállításon valaki kritikával illet egy festményt, de nem tudja, hogy azt a mellette álló barátja festette). Az ilyen helyzetek feldolgozása összetett mentális folyamatokat igényel: egyrészt tudatában kell lenni a faux past elkövető személy nézőpontjának, szándékának, valamint tudásának, másrészt a sértést vagy inzultust elszenvedő ember érzéseit is figyelembe kell venni (magyarul még lásd Gál et al., 2011).

Mivel a nyelvészeti és pszicholingvisztikai elméletek szerint az indirekt megnyilvánulások megértéséhez szükséges a kontextus ismeretén túl a szándéktulajdonítási képesség is (Pinker et al., 2008; Grice, 1957), így feltehetőleg különbséget találhatunk a 
közvetett beszédaktusok megértésében a mentális állapottulajdonítási képesség fejlettségében megmutatkozó eltérések miatt. Jelen kutatás tehát egyfelőlennek vizsgálatára is irányult.

\section{Munkamemória és mondatfeldolgozás}

Az indirekt beszéd kapcsán kevesebbet tárgyalt faktor az általános kognitív kapacitás hatása a nyelvi feldolgozásra. Több korábbi kutatás is kimutatta a munkamemória kapacitás szerepét az olvasott és hallott szövegek feldolgozása során (Jorm, 1983; Miles \& Ellis, 1981; King \& Just, 1991; Mason \& Just, 2007). Például Turi, Janacsek és Németh (2010) a munkamemória kapacitás és a kétértelmü mondatok feldolgozása közötti kapcsolatot vizsgálta, és azt találta, hogy a magasabb munkamemória kapacitással rendelkező személyek egyszerre mindkét jelentést fejben tudják tartani, míg a kisebb munkamemória kapacitású személyek a gyakoribb jelentést részesítik előnyben a mondat értelmezésénél.

Ezen kutatás eredményei alapján, mivel a hétköznapi életben gyakrabban használunk indirekt beszédaktusokat bizonyos (Pinker, Nowak \& Lee, 2008)) helyzetekben, azt feltételezzük, hogy az alacsonyabb munkamemória kapacitású személyek ezeket az indirekt megfogalmazásokat fogják előnyben részesíteni és gyorsabban feldolgozni a direkt megfogalmazású mondatokhoz képest. Ezzel szemben elképzelhető, hogy a magasabb munkamemória kapacitású személyeknél nincs különbség a kétféle megfogalmazás feldolgozási idejében, Turi és munkatársai (2010) eredményeihez hasonlóan.

\section{Célkitüzések}

Jelen kutatás célja, hogy az indirekt és direkt beszédaktusok idői feldolgozásának jellemzőit vizsgálja pszicholingvisztikai szempontból. A kutatás során a vizsgálati személyek történeteket olvasnak, melyek direkt vagy indirekt megfogalmazásokat tartalmaznak. Fő hipotézisünk szerint az indirekt mondatok feldolgozása gyorsabb lesz, mivel ezeket használjuk gyakrabban a vizsgált szituációkban (Pinker, Nowak \& Lee, 2008). Ezt a feldolgozást azonban befolyásolhatja a munkamemória korlátozott kapacitása. Az alacsonyabb munkamemória kapacitású személyek a direkt megfogalmazású mondatoknál lelassulhatnak, mivel ezek sérthetik a gyakoriság alapján kialakult elvárásaikat. Ezzel szemben feltételezzük, hogy a magasabb munkamemória kapacitású személyek ugyanolyan gyorsan dolgozzák fel a direkt és indirekt megfogalmazású mondatokat, mivel képesek több lehetséges elvárás és interpretáció egyidejű felállítására és fenntartására (Mason \& Just, 2007; Turi et al., 2010). 
Emellett feltételezésünk szerint az emberek mentális állapottulajdonítási képessége is befolyásolja a direkt és indirekt megfogalmazású mondatok feldolgozásának sebességét. A fejlettebb mentalizációs képesség megkönnyítheti az indirekt kifejezések értelmezését (gyorsabb feldolgozási idő), mivel a fejlettebb szándéktulajdonítás segíthet az adott szituáció értelmezésében és egyértelműsítésében. Ezzel szemben a történetek többi mondatánál, illetve a direkt megfogalmazású megnyilatkozások feldolgozási sebességénél nem lesz befolyásoló tényező az elmeteória-fejlettség, mivel itt a kijelentések elegendő információt tartalmaznak a szituáció megértéséhez.

\section{Módszerek}

\section{Résztvevö személyek}

A kutatásban 40 személy vett részt (33 nő és 7 férfi; átlagéletkor $=20,8$ év; szórás $=$ 3,04 év; átlagos iskolázottság = 13,35 év; szórás = 1,44 év). A mintát alkotó személyek a kísérletben önként vettek részt, a tesztek felvétele elött megfelelő tájékoztatásban részesültek és informált beleegyezési nyilatkozatot írtak alá. A vizsgálatok során az etikai normákat mindvégig betartottuk.

\section{Eszközök}

A direkt és az indirekt megfogalmazású mondatok feldolgozását egy reakcióidőméréses feladattal vizsgáltuk. A feladatban a vizsgálati személyek 25 történetet olvastak el számítógépen prezentálva, mondatonként megjelenítve. Az instrukció szerint az egyik mondat elolvasása után a következőt egy gomb lenyomásával jeleníthette meg a vizsgálati alany, ez tette lehetővé az egyes mondatok feldolgozási idejének mérését. Minden történet 11 mondatból állt, felépítésük egységes volt: az első nyolc bevezető mondat után következett valamelyik szereplő szájából egy, a történet kulcsmondatául szolgáló kijelentés, kérdés vagy felszólítás (9., kritikus mondat). A történetet további két mondat zárta le. Minden eseménysornak két változata létezett: egy direkt és egy indirekt, vagyis a kilencedik mondat megfogalmazási módjában tértek el. Annak érdekében, hogy ellenőrizhető legyen, hogy a vizsgálat résztvevői valóban figyelmesen elolvasták-e a történeteket, minden ötödik történet után kérdésekre kellett válaszolniuk az elolvasott eseménysorokkal kapcsolatban. Az öt mondatonként beiktatott szünet továbbá a fáradtsági hatás csökkentését is szolgálta. A mondatok bemutatása és a feladatvégzéssel kapcsolatos adatok rögzítése az E-prime programmal történt. 
A kutatás során a mentális állapottulajdonítási képesség fejlettségének mérésére az elterjedt „Faux pas” tesztet használtuk (Baron-Cohen et al., 1999, Gál et al., 2011). Ez a mérőeljárás 10 kontroll és 10 „faux pas” történetet tartalmaz. A vizsgálati személyeknek a kísérletvezető egyenként olvassa fel a történeteket, majd kérdéseket tesz fel a faux pas-k észlelésére és az eseménysorok megértésére vonatkozóan (pl. Mondott-e valaki olyat, amit nem kellett volna? Ha igen, akkor ki?, stb.). A torzító emlékezeti hatások elkerülése érdekében a kísérletben résztvevők a saját példányukon keresztül folyamatosan nyomon követhetik a történeteket, valamint a válaszadáshoz is felhasználhatják a szöveget. A kontroll történetekre összesen 20, a „faux pas” történetekre 60, míg a megértést ellenőrző kérdésekre 40 pontot kaphatnak maximálisan az alanyok.

A kutatási eszközök részét képezték elterjedt munkamemória-mérő eljárások is. Az első teszt a munkamemória-modellben fonológiai hurokként elnevezett, a beszédszerü információ tárolásáért felelős komponenst (Baddeley \& Hitch, 1974) mérő Számterjedelemteszt (Digit Span, Jacobs, 1887; Racsmány, Lukács, Németh, \& Pléh, 2005). Ebben a feladatban a vizsgálati személyeknek az egy másodperces szünetekkel elhangzott számjegyeket kell visszamondani a bemutatás sorrendjében. Kezdetben három számjegyből áll egy sorozat, majd négy számsor elhangzása után növekszik a sorozat elemszáma egészen addig, amíg a vizsgálati személy nem képes legalább négy próbából három számsort helyesen megismételni. Az utolsó sikeresen megismételt sorozat hosszúsága lesz a kísérleti személy számterjedelme.

A második munkamemóriával kapcsolatos mérőeljárás a komplex munkamemóriát tesztelő Hallási Mondatterjedelem Teszt (Listening Span, magyar változat: Janacsek, Tánczos, Mészáros \& Németh, 2009). A hallási mondatterjedelem tesztnél a vizsgálatvezető mondatok olvas fel a kísérlet személynek, akinek döntést kell hoznia az adott állítás igazságtartalmáról, melynek célja a figyelem és a megértés ellenőrzése. A mondatok felolvasását követően azok utolsó szavait kell megismételnie a vizsgálati alanynak, abban a sorrendben, ahogy elhangzottak. Összesen három sorozat felvétele szükséges. Mindegyik sorozatban először két mondat utolsó szavait kell megismételni, majd a mondatok száma emelkedik, egészen addig, amíg a vizsgálati személy nem képes helyes sorrendben visszamondani az elhangzott mondatok utolsó szavait. A hallási mondatterjedelem teszt végeredménye a három sorozat átlaga lesz.

A harmadik, szintén komplex munkamemóriát mérő teszt a Számlálási Terjedelem Teszt volt (Counting Span; Case, Kurland \& Goldberg, 1982). A feladatban a vizsgálati személynek a számítógép képernyőjén megjelenő ábrahalmazban (kék és sárga körök, 
valamint kék négyzetek) kell hangosan kimondva, egyesével megszámolnia a sötétkék köröket, majd a végeredményt megismételni és megjegyezni. Ezt követően ismét megjelenik egy ábra, majd az előbbi számolási feladat elvégzése után a kísérleti személynek vissza kell mondania a két végeredményt a bemutatás sorrendjében. A kék körök száma mindig kettő és nyolc közé esik, ismétlődés a számok között nincs egy próbán belül. A mủvelet sikeres végrehajtása esetén eggyel emelkedik a megjegyzendő számok mennyisége. Hibázás esetén egy új sorozat veszi kezdetét, ismét két számlálási feladattal, illetve a megjegyzett eredmények visszamondásával. A három sorozat átlaga adja a személy számlálási terjedelmét, amely minimálisan egy, maximálisan pedig hat lehet.

\section{Ingeranyag}

A reakcióidö-méréses feladatban a történetek a Pinker és munkatársai (2008) által meghatározott öt csoport alapján alakultak ki, melyekkel kapcsolatban az emberek a leggyakrabban használnak indirekt kifejezéseket (az öt kategória: udvarias kérés, mérsékelt utasítás, rejtett fenyegetés, szexuális tartalmú felhívás és leplezett megvesztegetés). A történeteket részben a szakirodalomból vett példák alapján, részben pedig a hétköznapi helyzetekben előforduló szituációk leírásával alkottuk meg. Az ingeranyag kidolgozása során független, a kutatásban részt nem vevő személyek véleményét is kikértük a történetek érthetőségének biztosítása érdekében. Mind az öt kategóriában öt különböző történetet olvastak a kísérleti személye (a történeteket lásd a 1. számú mellékletben). Alább olvasható egy példa a reakcióidő-mérésen alapuló vizsgálatban szereplő történetek közül (a példatörténet a leplezett megvesztegetés kategóriájából származik).

1. mondat: Péter ügyvédként dolgozott egy pénzügyi vállalatnál.

2. Egy tárgyalásra vezetett, amikor szirénázást hallott.

3. Egy rendőrautó követte, és lehúzódásra intette őt.

4. Péter leparkolta járművét a leállósávba.

5. A rendör odasétált Péterhez, hogy igazoltassa őt.

6. Továbbá közölte, hogy Péter túl gyorsan hajtott.

7. A tiszt meg is kezdte a büntetőcédula megírását.

8. Péter sietett, ezért feltette a következő kérdést:

9.a. Biztos úr, nem intézhetnénk el a bírságot másként? (indirekt változat)

9.b. Biztos úr, adok ötezer forintot, ha elenged. (direkt változat)

10. A rendőr feljelentette őt vesztegetés gyanújával.

11. A bíróságon azonban tisztázni tudta magát. 
A mondatok szótagszámai ki voltak egyenlítve annak érdekében, hogy a feldolgozási időben megmutatkozó különbségek ne lehessenek a mondatok hossza közötti eltéréseknek tulajdoníthatók. A feladatnak készült két változata, mindkettőben szerepelt a 25 történet, azonban az egyes történetek különböztek megfogalmazásukban: amíg az egyikben egy történet direkt megfogalmazásban szerepelt, addig ugyanezen történet kulcsmondatának indirekt verziója volt megtalálható a másik változatban. A sorrendi hatás elkerülésének érdekében a feladat mindkét változatának készült egy-egy olyan típusa, ahol a történetek ellentétes sorrendben kerültek bemutatásra. Így összesen négy féle eltérő történet-sorozattal volt mérhető a mondatok feldolgozási sebessége, melyek csak a történetek bemutatási sorrendjében, illetve a kulcsmondatok megfogalmazási módjában tértek el. A feladattípusok közül minden kísérleti személy egyet olvasott végig, tehát egy történettel egyszer találkozott.

Az elemzés során három csoportot kialakítva elemeztük a feldolgozással töltött időt: önálló változóként szerepelt az első nyolc mondatra adott reakcióidők mediánja, külön értékként a kritikus kilencedik mondattal kapcsolatos feldolgozási idők átlaga, illetve szintén összevonva kezeltem az utolsó két mondat olvasásával töltött idők mediánját.

\section{A kisérleti eljárás}

A kísérlet minden esetben a résztvevő személy tájékoztatásával és az informált beleegyezési nyilatkozat aláírásával vette kezdetét. Ezután következtek a mérőeljárások, melyek sorrendje minden kísérleti személynél véletlenszerüen alakult a sorrendi hatás elkerülése érdekében. A reakcióidő-mérésen alapuló eljárásnál összetartozó mintás (within subject) elrendezést alkalmaztunk, tehát a kísérleti személyek mind a két feltételből (direkt és indirekt kulcsmondat) olvastak történeteket. A tájékoztatás és az öt feladat felvétele körülbelül egy órát vett igénybe.

\section{Adatelemzés}

Az adatok elemzése során a 40 fős mintából egy ember adatait kellett kihagyni a reakcióidőkben megmutatkozó szélsőségesen magas értékek miatt (a célmondatoknál 4500 milliszekundum (ms), ami jóval meghaladta a többi vizsgálati személy értékét, akiknél az átlag 2556,54 ms volt a direkt (szórás $=496,74 \mathrm{~ms}$ ) és $2696,61 \mathrm{~ms}$ az indirekt mondatok esetében (szórás $=463,81 \mathrm{~ms})$ ). A történetek után feltett kérdésekre, amelyek az olvasott szövegek feldolgozását ellenőrizték, minden résztvevő személy helyes válaszokat adott, így emiatt senkit sem kellett kihagyni a mintából. 
A munkamemória kapacitás hatásának elemzéséhez egy magas- és egy alacsony munkamemória terjedelmü csoportot hoztunk létre minden egyes teszt esetében. A csoportok kialakítása lehetőség szerint közel egyenlő elemszámmal történt, azonban ez a törekvés a kis szórás miatt korlátokba ütközött. A számterjedelem teszt esetében a 6-os, illetve az annál kisebb pontszámot elérő személyek kerültek az alacsonyabb munkamemória-kapacitású csoportba $(n=24)$, míg az adott értéknél jobb teljesítményt mutatók alkották a magasabb munkamemória-kapacitású csoportot $(\mathrm{n}=15)$. A Hallási Mondatterjedelem Teszt esetében a 3,66-os érték alapján hoztunk létre két csoportot, így 23 ill. 16 személy került az alacsonyabb és magasabb teljesítményü csoportba. A Számlálási Terjedelem Teszt esetében is a 3,66-os átlag alapján történt a csoportosítás (22 vs. 17 k.sz.).

A Faux Pas feladattal kapcsolatos elemzésekből ki kellett hagynunk három személyt a teszt ismerete miatt, illetve kettő alanyt a feladat feltehető félreértése miatt (pontszámaik 0 és 11 voltak a maximálisan elérhető hatvanból a teszt faux pas történetekre vonatkozó mutatóján). A teszttel kapcsolatos elemzés végleges elemszáma így 34 före módosult (28 nő és 6 férfi; átlagéletkor $=20,76$ év; szórás $=3,26$ év; átlagos iskolázottság $=13,18$ év; szórás $=$ 1,36 év). Az adatok elemzéséhez két csoportot alakítottunk ki a teszt faux pas történeteire kapott pontszámok alapján. A magasabb elmeteória pontszámmal rendelkező csoport az 52 pontnál többet elért személyekből állt $(\mathrm{n}=17$ fö), míg a másik csoportot az 52 pontot, vagy annál kevesebbet kapott alanyok alkották $(\mathrm{n}=17$ fö $)$.

\section{Eredmények}

A direkt és indirekt mondatok feldolgozása, illetve kapcsolata a munkamemória-kapacitással

A munkamemória-kapacitás mondatfeldolgozásra gyakorolt esetleges hatását ismételt méréses varianciaanalízissel elemeztük, külön mindhárom teszt esetében. Azt feltételeztük, hogy az alacsonyabb munkamemória kapacitású személyek az indirekt megfogalmazásokat fogják előnyben részesíteni és gyorsabban feldolgozni a direkt megfogalmazású mondatokhoz képest. A magasabb munkamemória kapacitású személyek esetében nem vártunk különbséget a kétféle megfogalmazás feldolgozási idejében, Turi és munkatársai (2010) eredményeihez hasonlóan.

A variancia-analízisben szerepelt egy összetartozó mintás faktor a kulcsmondat TÍPUS-a alapján (direkt vagy indirekt megfogalmazás), illetve egy független mintás faktor a munkamemória teljesítmény alapján kialakított CSOPORT-ok szerint (alacsony vagy magas 
kapacitás). A varianciaanalízis szignifikáns TíPUS főhatást mutatott $(\mathrm{F}(1,31)=4,499 ; \mathrm{p}=$ 0,042): a direkt mondatok feldolgozása gyorsabb volt, mint az indirekt megfogalmazásúaké (2556 vs. 2696 ms; lásd 1. ábra). Az eredmények szerint a munkamemória kapacitásban megmutatkozó egyéni különbségek nem tehetők felelőssé a direkt és indirekt mondatok feldolgozási ideje között megfigyelt eltérésekért (nem szignifikáns CSOPORT x TÍPUS interakció: a Számterjedelem Teszt esetében a $\mathrm{F}(1,31)=0,359 ; \mathrm{p}=0,553$; a Hallási Mondatterjedelem Teszt esetében $\mathrm{F}(1,31)=1,681 ; \mathrm{p}=0,204$; míg a Számlálási Terjedelem Teszt esetében $F(1,31)=0,1 ; p=0,754)$.

1. ábra

1, ábra: A direkt és az indirekt mondatok feldolgozási ideje között szignifikáns különbség található: a direkt mondatok feldolgozása gyorsabb volt mint az indirekt mondatoké. Az ábrán a hibasávok az átlag standard hibáját mutatják. *p<0,05

Az első nyolc mondat elemzésére is hasonló varianciaanalízist végeztünk el, melyben nem mutatkozott szignifikáns TÍPUS főhatás $(\mathrm{F}(1,31)=0,001 ; \mathrm{p}=0,981)$, vagyis a vizsgálati személyek hasonló reakcióidőkkel választoltak az indirekt és direkt megfogalmazású történetek első nyolc mondatára. Nem volt hatása a feldolgozási időre a munkamemóriateljesítménynek sem (nem szignifikáns TÍPUS x CSOPORT kereszthatás: Számterjedelem Teszt esetében $\mathrm{F}(1,31)=0,256 ; \mathrm{p}=0,616$; a Hallási Mondatterjedelem Teszt esetében $\mathrm{F}(1,31)$ $=0,082 ; \mathrm{p}=0,777$; a Számlálási Terjedelem Teszt esetében $\mathrm{F}(1,31)=0,346 ; \mathrm{p}=0,561$ ).

Az utolsó két mondaton sem vártunk különbséget a direkt és az indirekt mondatokat követő szövegrészeket összehasonlítva. A varianciaanalízis megerősítette a hipotézist, ugyanis nem mutatkozott szignifikáns TÍPUS föhatás $(\mathrm{F}(1,31)=0,528 ; \mathrm{p}=0,473)$. Azonban a Számlálási Terjedelem Teszt esetében a TÍPUS x CSOPORT interakció szignifikáns lett $(\mathrm{F}(1,31)=7,290 ; \mathrm{p}=0,011$; lásd 2. ábra $)$ : a magasabb pontszámot elért csoport reakcióideje szignifikánsan gyorsabb volt az indirekt mondatok prezentációját követően szemben a direkt mondatokéval $(\mathrm{p}=0,028)$. Ezzel szemben az alacsonyabb munkamemória-teljesítményü csoport reakcióideje egyforma mértékủ volt a direkt és az indirekt mondatok prezentációját követően is $(\mathrm{p}=0,275)$. A direkt mondatok esetében az alacsonyabb és magasabb munkamemória kapacitású személyek reakcióideje nem különbözött szignifikánsan ( $\mathrm{p}$ = 
0,431), az indirekt mondatok esetén viszont a magasabb munkamemória kapacitású személyek gyorsabbak voltak $(p=0,037)$. A másik két munkamemória-teszten nem mutatkozott szignifikáns TÍPUS x CSOPORT kereszthatás (Számterjedelem Teszt: F(1,31) = 1,149; $p=0,292$; Hallási Mondatterjedelem Teszt: $F(1,31)=0,428 ; p=0,518$ ).

2. ábra

2. ábra: A Számlálási Terjedelem Teszten magasabb pontszámot elért csoport szignifikánsan gyorsabban reagált az indirekt mondatok után, mint a direkteket követöen. Az alacsonyabb teljesitményü csoport esetében nincs különbség a reakcióidők között. Az ábrán a hibasávok az átlag standard hibáját mutatják. * $p<0,05$

Az előző eredmény pontosabb megértése érdekében egy másik elemzési szempont alapján is megvizsgáltuk a kapott adatokat. Eszerint az ismételt méréses varianciaanalízisben egyszerre vizsgáltuk a mondat TÍPUS-át (direkt vagy indirekt,), a MONDAT-ot (8., a 9. és a 10. mondaton kapott reakcióidők), illetve a CSOPORT-ot (a Számlálási Terjedelem Teszt alapján alacsony vagy magas munkamemória kapacitás). Habár a TÍPUS x CSOPORT x MONDAT hármas interakció nem szignifikáns $(\mathrm{p}=0,236)$, a post hoc tesztek eredményei szerint van különbség a munkamemória csoportok között a direkt és az indirekt mondatok feldolgozásának mintázatában. Összességében a 9., kulcsmondaton a nyolcadikhoz és a tizedikhez képest is lassulás figyelhető meg (minden $p<0,001$ ), mely eredmény ugyanúgy igaz az alacsony és a magas munkamemória terjedelem esetén is (minden $\mathrm{p}<0,026$ ). Azonban míg az alacsonyabb munkamemória kapacitású csoport mind a direkt, mind pedig az indirekt mondatoknál szignifikánsan lassabb reakcióidőt mutat (minden $\mathrm{p}<0,035$; lásd 3. ábra), addig a magasabb munkamemória terjedelmủ csoport csak az indirekt megfogalmazású mondatoknál mutat lassabb feldolgozási időt (minden $\mathrm{p}<0,003$ ), a direkt mondatok esetében nincs szignifikáns lassulás (minden $\mathrm{p}>0,274$; lásd 3. ábra).

3. ábra

3. ábra: (A) Az alacsonyabb számlálási terjedelmü csoport mind a direkt, mind az indirekt kulcsmondatok esetében szignifikánsan lassabb reakcióidöt mutatott, mint a 8. és a 10. mondat esetében. (B) A Számlálási Terjedelem Teszt alapján magasabb munkamemória terjedelmü csoport reakcióidöinél csak az indirekt 
mondatok esetében figyelhetö meg szignifikáns lassulás a 9. mondat feldolgozásában. A direkt mondatok reakcióidői statisztikailag nem különböznek a 8. és a 10. mondat feldolgozásához szükséges időtől. Az ábrán a hibasávok az átlag standard hibáját mutatják. * $p<0,05, * * p<0,01$

\section{Mondatfeldolgozás és mentális állapottulajdonitás}

A kutatás összefüggést feltételezett a mentális állapottulajdonítási képesség fejlettsége és az indirekt kulcsmondatok feldolgozási sebessége között, ugyanakkor nem tartotta befolyásoló faktornak az elmeteória-fejlettséget a direkt megfogalmazású megnyilvánulások és a történet többi mondatának reakcióidejének alakulásában. A hipotézis szerint a fejlettebb mentalizációs képesség megkönnyítheti az indirekt kifejezések értelmezését, így gyorsabb feldolgozási időt eredményez, mivel a fejlettebb szándéktulajdonítás segíti az adott szituáció értelmezését és egyértelműsítését. Ezzel szemben a történetek többi mondatánál, illetve a direkt megfogalmazású megnyilatkozások feldolgozási sebességénél nem lesz befolyásoló tényező az elmeteória-fejlettség, mivel itt a kijelentések elegendő információt tartalmaznak a szituáció megértéséhez.

A két csoport reakcióidőit a történetek kulcsmondataira (9. mondat) ismételt méréses varianciaanalízissel hasonlítottuk össze, ahol a TÍPUS (direkt vagy indirekt módon megfogalmazott mondat) összetartozó mintás faktor és a CSOPORT (alacsony vagy magas faux pas pontszám) független mintás faktor szerepeltek. Az ANOVA szignifikáns TÍPUS főhatást mutatott $(\mathrm{F}(1,32)=14,270 ; \mathrm{p}=0,001)$, ami arra utal, hogy a személyek eltérő reakcióidővel dolgozták fel a vizsgált kilencedik mondat direkt és indirekt változatát (2560,44 ms vs. 2725,59 ms). Ez az eredmény megegyezik a teljes mintán kapott eredménnyel. A TÍPUS x CSOPORT interakció nem lett szignifikáns $(\mathrm{F}(1,32)=0,7 ; \mathrm{p}=0,409)$. A faux pas feladaton jobban teljesítő csoport ugyanis nem csak az indirekt, hanem a direkt mondatokat is gyorsabban dolgozta fel a gyengébben teljesítő elmeteória-csoportnál (CSOPORT főhatás: $\mathrm{F}(1,32)=14,27 ; \mathrm{p}=0,001)$ (lásd 4. ábra).

\section{4. ábra}

4. ábra: A hipotézissel ellentétben nem figyelhetö meg szignifikáns kereszthatás a különbözö mentalizációs képességekkel bíró csoportok között a kilencedik mondaton mutatott reakcióidök tekintetében, habár a magasabb Faux pas pontszámot szerzett csoport mindkét mondattípus esetében alacsonyabb válaszidöt mutatott. Az ábrán a hibasávok az átlag standard hibáját mutatják. 
Az első nyolc mondat olvasása esetén nincs szignifikáns TÍPUS főhatás $(\mathrm{F}(1,32)=$ 0,339; $\mathrm{p}=0,565)$, valamint a TÍPUS x CSOPORT interakció sem szignifikáns $(\mathrm{F}(1,32)=$ $0,108 ; \mathrm{p}=0,745)$. A történet utolsó két mondatát tekintve is hasonló eredményeket kaptunk, vagyis nem figyelhető meg szignifikáns TíPUS főhatás a 9. mondatot követő két mondaton mutatott reakcióidők mediánjai között $(\mathrm{F}(1,32)=0,094 ; \mathrm{p}=0,761)$, illetve a TÍPUS $\mathrm{x}$ CSOPORT kereszthatás sem szignifikáns $(\mathrm{F}(1,32)=2,262 ; \mathrm{p}=0,142)$, a mentalizációs képesség tehát ebben az esetben nem befolyásolta a mondatok feldolgozásának sebességét.

\section{Megvitatás}

Jelen kutatás fő célja az indirekt beszédaktusok vizsgálata volt, azonban a korábbi kutatásoktól eltérően mi nem a jelenség hátterében meghúzódó logikai és stratégiai okok feltárására fókuszáltunk, hanem arra, hogy az indirekt mondatoknak a direkt mondatokhoz képest van-e előnyük az online feldolgozási időkben. A kísérlet választ keresett továbbá arra a kérdésre is, hogy a társas (elmeteória) és az általános kognitív képességek befolyásolják-e az indirekt mondatok feldolgozását. A mérőeljárások közé tartozott egy reakcióidő-mérésen alapuló feladat, melyben a kísérletben résztvevő személyeknek 25 történet direkt vagy indirekt kulcsmondatot tartalmazó változatát kellett elolvasniuk önütemezett olvasási helyzetben. A kísérleti alanyok elmeteória-fejlettségének mérése az elterjedt Faux Pas teszttel történt (Baron-Cohen et al., 1999), az általános kognitív képesség pedig munkamemória tesztekkel lett feltérképezve.

Annak ellenére, hogy a hétköznapi szituációk során gyakran élünk a közvetett beszédaktusok használatával, hipotézisünkkel szemben az eredményeink azt mutatják, hogy a kísérleti személyek gyorsabban dolgozták fel a direkt mondatokat az indirektekhez képest. Ennek egy lehetséges magyarázata, hogy az indirekt közlések során a kétértelmüség feldolgozása több kognitív erőforrást igényel. Az indirekt megnyilatkozások használatának előnyei ezek szerint meg kell, hogy haladják a nehezebb és lassabb feldolgozás jelentette hátrányt. Ezek az előnyök jelenthetik a beszédpartnerek arculatának védelmét, az indirekt kifejezés nyújthat elfogadható tagadhatóságot, vagy segítheti a kapcsolati állapot tisztázását (Pinker et al., 2008).

A továbbiakban azt is megvizsgáltuk, hogy a munkamemória kapacitás befolyásolja-e a mondatok feldolgozási sebességét. Az első nyolc illetve a 9. kulcsmondat esetében nem különbözött az alacsonyabb és a magasabb munkamemória kapacitású csoportok reakcióideje. Ezzel szemben az utolsó két mondat esetében jelentős különbség volt a két csoport között. A két csoport feldolgozási ideje különbözött az indirekt megfogalmazású kulcsmondatok utáni 
szakaszban szemben a direkt megfogalmazású kulcsmondatokat követő szakaszok feldolgozásával, ahol nem találtunk különbséget. Mivel az inger itt mindig ugyanaz volt, a különbség az előző (kritikus) mondat további feldolgozásával függhet össze. Az alacsonyabb munkamemóriájú személyeknél egy „elhúzódóbb” feldolgozást feltételezhetünk az indirekt megfogalmazású mondatok esetén a magasabb munkamemória kapacitású csoporthoz képest.

A két munkamemória csoport feldolgozási mintázatának részletesebb elemzése rávilágított, hogy további jellegzetes különbség figyelhető meg a reakcióidőkben a munkamemória kapacitás függvényében. Ugyan a kulcsmondat (9.) reakcióideje összességében nem különbözött az alacsony és magas munkamemória kapacitású csoport között, azonban mindkét csoport szignifikánsan lassabban dolgozta fel a 9. kulcsmondatot a nyolcadikhoz és a tízedikhez képest. A két csoport reakcióidői más mintázat szerint változtak: az alacsonyabb Számlálási Terjedelem pontszámot elért személyek mind a direkt, mind pedig az indirekt mondatokon megnövekedett feldolgozási időt mutattak. Ezzel szemben a Számlálási Terjedelem Teszt alapján magasabb munkamemória terjedelmű alanyok csak az indirekt mondatokon mutattak reakcióidő-növekedést, a direkt mondatoknál nem következett be lassulás. Ez a jelentős különbség magyarázható azzal, hogy az alacsonyabb munkamemória kapacitás a gyakoribb, indirekt megfogalmazás értelmezését készíti elö, és a direkt megfogalmazás megsérti az elvárásokat, ami pedig lassuláshoz vezet. Ezzel szemben magasabb munkamemória kapacitás esetén több lehetséges (direkt és indirekt) megfogalmazás és interpretáció is kialakulhat, és mivel a direkt megfogalmazásnál csak egy, egyértelmü jelentés van, ezért az gyorsabb feldolgozáshoz vezet a kétértelmü, indirekt megfogalmazáshoz képest. Tehát a kulcsmondatnál kerül sor az adott történet értelmezésére, egyértelmüsítésére, ami az alacsonyabb munkamemória kapacitású személyek számára lassabb reakcióidőhöz vezet mind a direkt, mind az indirekt mondatok esetében. Ezzel szemben a magasabb munkamemória kapacitású személyek elegendő erőforrással rendelkeznek a direkt megfogalmazást tartalmazó történetek gyors értelmezéséhez, így nem lassulnak le, csak az indirekt mondatoknál.

A kutatás másik hipotézise a résztvevő személyek mentális állapottulajdonítási képességének szintje, és az indirekt mondatok feldolgozási ideje közötti összefüggésekre vonatkozott. Grice (1957) átfogó nyelvelméletében is fontos szerepe van a szándéktulajdonításnak a kommunikációban, de az elmeteória pszichológiai fogalmának definíciójából (Brüne \& Brüne-Cohrs, 2006) is következtethetünk arra, hogy az indirekt mondatok feldolgozásához szükségünk lehet arra a képességre, hogy másoknak gondolatokat, szándékot, motivációt és érzelmeket tulajdonítsunk. Eredményeink azt mutatják, hogy a Faux 
Pas teszten kapott pontszámok alapján magasabb elmeteória-pontszámmal rendelkező személyek gyorsabban dolgozzák fel mind a direkt, mind az indirekt megfogalmazású mondatokat az alacsonyabb pontszámokat elérő személyekhez képest. Tehát nem egy, a megfogalmazásra (direkt vs. indirekt) vonatkozó specifikus hatásról van szó, hanem egy általánosabb feldolgozási előnyre utal. Ez a gyorsabb általános feldolgozási idő jelzi, hogy a mentalizációs képességek segítik a szociális helyzetek megértését a mondatok megfogalmazásától függetlenül.

Összefoglalva, a különböző megfogalmazású mondatok feldolgozása eltérő reakcióidővel történik, amelynek mértékére befolyásoló hatással van a munkamemóriakapacitás és általánosságban a mentális állapottulajdonítási képesség fejlettsége is. Annak ellenére, hogy a hétköznapi életben gyakran használjuk az indirekt megfogalmazást, mégis lassabban dolgozzuk fel. Akinek pedig alacsonyabb a munkamemória kapacitása, további hátrányban van a feldolgozás során. Fontos kiemelni, hogy a kutatás az indirekt beszédaktusok jelenségét egy új szempontból közelítette meg, a beszédforma használata mögött meghúzódó stratégiai okok helyett a nyelvi feldolgozást előtérbe helyezve. Továbbá eredményeink módszertani szempontból rávilágítanak arra is, hogy a mondatok értelmezésének vizsgálatakor lényeges szempont a kritikus mondat elemzésén túl az utána következő szövegrész vizsgálata is, amely elengedhetetlen a jelenség megértéséhez.

\section{Köszönetnyilvánítás}

Köszönjük Németh Zsuzsannának a cikk megírásához nyújtott hasznos tanácsait. A kutatást az OTKA NF 105878 támogatta. 


\section{Felhasznált irodalom}

Alexander, R. D. (1987). The Biology of Moral Systems. New York, NY: Aldine de Gruyter, Hawthorne.

Austin, J. L. (1962). How to do Things with Words. Cambridge, MASS: Harvard University Press. Magyarul: Austin, J. L. (1990). Tetten ért szavak. Budapest: Akadémiai Kiadó.

Baddeley, A. D., \& Hitch, G. (1974). Working memory. In Bower, G. A. (ed.) Recent advances in learning and motivation. Vol. 8., New York, NY: Academic Press.

Baron-Cohen, S., Jolliffe, T., Mortimore, C., \& Robertson, M. (1997). Another advanced test of theory of mind: evidence from very high functioning adults with autism or Asperger Syndrome. Journal of Child Psychology and Psychiatry, 38, 813-822.

Baron-Cohen, S., O’Riordan, M., Jones, R., Stone, V., \& Plaisted, K. (1999). A new test of social sensitivity: Detection of faux pas in normal children and with Asperger sydrome. Journal of Autism and Developmental Disorders, 29, 407-418.

Brown P., \& Levinson S. C. (1987). Politeness: Some Universals in Language Usage. New York, NY: Cambridge Universal Press.

Brüne, M., \& Brüne-Cohrs, U. (2006). Theory of mind - evolution, ontogeny, brain mechanisms and psychopatology. Neuroscience and Biobehavioral Reviews, 30(4), 437 455.

Case, R., Kurland, D. M., \& Goldberg, J. (1982). Operational efficiency and the growth of short-term memory span. Journal of Experimental Child Psychology, 33(3), 386-404.

Dawkins, R., \& Krebs, J. R. (1978). Animal signals: Information or manipulation? in Behavioral Ecology, eds Krebs, J. R. \& Davies, N. B., Blackwell, Oxford, pp. 282309.

della Porta, D., \& Vanucci, A. (2005). The moral (and immoral) costs of corruption. In: Dimensionen politischer Korruption, Sonderheft der Politischen Vierteljahresschrift (pp. 109-134). Wiesbaden: VS Verlag für Sozialwissenschaften.

Fiske, A. P. (1992). The four elementary forms of sociality: Framework for a unified theory of social relations. Psychological Review, 99, 689-723.

Fiske, A. P. (2004). Four modes of constituting relationships: Consubstantial assimilation; space, magnitude, time, and force; concrete procedures; abstract symbolism. Relational Models Theory: A Contemporary Overview, ed. Haslam, N., Erlbaum Associates, Mahwah, NJ.

Gál, Z., Egyed, K., Pászthy, B., \& Nemeth, D. (2011). Tudatelméleti deficit anorexia nervosában. Psychiatria Hungarica, 26(1), 12-25. 
Gibbs, R. W. (1983). Do people always process the literal meanings of indirect requests? Journal of Experimental Psychology: Learning, Memory, and Cognition, 9, 524-533.

Goffman, E. (1967). Interaction ritual: Essays on face-to-face behavior. New York, NY: Anchor Books.

Grice, H. P. (1957). Meaning. The Philosophical Review, 66, 377-388.

Grice, H. P. (1975). Logic and Conversation. In: Cole, P., \& Morgan, J. L. (eds.): Syntax and Semantics Vol. 3:, Speech Acts. (pp. 41-58). New York: Academic Press.

Hamilton, W. D. (1964a). The genetical evolution of social behaviour. I. Journal of Theoretical Biology 7, 1-16.

Hamilton, W. D. (1964b). The genetical evolution of socialbehaviour. II. Journal of Theoretical Biology 7, 17-52.

Holtgraves, T. M. (1994). Communication in context: Effects of speaker status on the comprehension of indirect requests. Journal of Experimental Psychology: Learning, Memory, and Cognition, 20, 1205-1218.

Jacobs, J. (1887). Experiments on ,prehension”. Mind, 12, 75-79.

Jagodics, B., \& Németh, D. (2012). A stratégiai beszélő elmélete - Az indirekt beszédaktusok használatának pszichológiai háttere. Magyar Pszichológiai Szemle, 67(4), 757-776.

Janacsek, K., Tánczos, T., Mészáros, T., \& Németh, D. (2009). A munkamemória új neuropszichológiai mérőeljárása: a hallási mondatterjedelem teszt (HMT). Magyar Pszichológiai Szemle, 64(2), 385-406

Jorm, A. F. (1983). Specific reading retardation and working memory: A review. British Journal of Psychology, 74, 311-342.

Just, M. A., \& Carpenter, P. A. (1992). A Capacity Theory of Comprehension: Individual Differences in Working Memory. Psychological Review, 99(1), 122-149.

Kahneman, D., \& Tversky, A. (1979). Prospect theory: An analysis of decisions under risk. Econometrica, 47, 313-327.

King, J., \& Just, M. A. (1991). Individual differences in syntactic processing: The role of working memory. Journal of Memory and Language, 30(5), 580-602.

Kovács, Á. M., Téglás, E., \& Endress, A. D. (2010). The Social Sense: Susceptibility to Others' Beliefs in Human Infants and Adults. Science, 330, 1830-1834.

Lee, J. J., \& Pinker, S. (2010). Rationales for Indirect Speech: The Theory of Strategic Speaker, Psychological Review, 117(3), 785-807. 
Mason, R.A. and Just, M.A. (2007). Lexical ambiguity in sentence comprehension. In T. Swaab (Ed.) Brain Research, Special Issue: Mysteries of Meaning, 1146, 115-127.

Maynard Smith, J. (1982) Evolution and the Theory of Games. Cambridge: Cambridge University Press.

Miles, T. R., \& Ellis, N. C. (1981). A lexical encoding difficulty II: Clinical observations. In Pavlidis, G. Th., \& Miles, T. R. (eds): Dyslexia research and its applications to education. Chichester: Wiley, 217-244.

Moody-Stuart, G. (1997). Grand corruption. How business bribes damage developing countries. Oxford: WorldView Publishing.

Nowak, M. A. (2006). Five rules for the evolution of cooperation. Science, 314, 1560-1563.

Perner, J., \& Wimmer, H. (1985). 'John thinks that Mary thinks that...' Attribution of secondorder beliefs by 5-10 year old children. Journal of Experimental Child Psychology, $39,437-471$.

Pinker, S., Nowak, M. A., \& Lee, J. J. (2008). The logic of indirect speech. PNAS, 105(3), 833-838.

Pléh, Cs. (2012). A társalgás pszichológiája. Budapest: Libri Kiadó.

Racsmány M., Lukács Á., Németh D., \& Pléh Cs. (2005). A verbális munkamemória magyar nyelvü vizsgálóeljárásai. Magyar Pszichológiai Szemle, LX 4, 479-505.

Searl, J. R. (1975). Indirect speech acts. 59-82. In: Cole, P., \& Morgan, J. (szerk.) (1975). Syntax and Semantics. New York: Academic Press. Magyarul: Közvetett beszédaktusok. In: Pléh, Cs., Síklaki, I., \& Terestyányi, T., (szerk) (1997). Nyelv kommunikáció - cselekvés. Budapest: Osiris.

Schelling, T. C. (1960). The Strategy of Conflict, Cambridge, MA: Harvard University Press.

Tooby, J., \& Cosmides, L. (1996). Friendship and the Banker's Paradox: Other pathways to the evolution of adaptations for altruism. Proceedings of the British Acadadaóeny, 88, $119-143$.

Trivers, R. (1971). The evolution of reciprocal altruism. The Quarterly Review of Biology, 46, $35-57$.

Trivers, R. (1985). Social Evolution, Reading, MA: Benjamin/Cummings.

Turi, Zs. Janacsek, K. \& Németh, D. (2010). A munkamemória, a szógyakoriság és a kontextus szerepe a lexikális kétértelműség feldolgozásában. Pszichológia, 4, 295-315.

Williams, G. C. (1966). Adaptation and Natural Selection: A Critique of Some Current Evolutionary Thought, Princeton: Princeton University Press. 
Wimmer, H., \& Perner, J. (1983). Beliefs about beliefs: Representation and constraining function of wrong beliefs in young children's understanding of deception. Cognition $13,103-128$. 


\section{Mellékletek}

\section{1. számú melléklet: Példák a reakcióidő-méréses feladatban használt történetekre}

\section{Szexuális tartalmú utalás kategóriája:}

József és Kata egy házibuliban ismerkedtek meg. (15 szótag)

Egy héttel később József randira hívta Katát. (14)

Egy közeli olasz étterembe mentek vacsorázni. (16)

A pincértől egy kétszemélyes fogást rendeltek. (14)

Az ételhez egy üveg bort is elfogyasztottak. (14)

A vacsora végére mindketten jó hangulatba kerültek.

(18)

A fizetés után sétálni indultak a környéken. (16)

A saját lakása közelében József megszólalt: (15)

$>$ Lenne kedved megnézni a bélyeggyüjteményemet? (15, indirekt)

$>$ Lenne kedved feljönni hozzám, hogy lefeküdj velem? (15, direkt)

Kata rögtön nemet mondott a meglepő kérdésre. (15) Pár nap múlva azonban újra találkozott Józseffel. (16)

\section{Mérsékelt utasítás kategóriája:}

Peti egy óvódás korú testvér nélküli kisgyermek. (16)

A szüleivel él Szegeden egy kertes családi házban. (17)

A sok játszópajtás miatt szeret óvodába járni. (15)

Otthon is gyakran tartanak zsúrokat a barátainak. (17)

Ilyenkor rendszerint nagy rendetlenséget csinálnak. (15)

Peti azonban nem szívesen segít a takarításban. (17)

A szülei viszont igyekeznek változtatni ezen. (16)

Az egyik délutánt követően édesanyja így szólt: (16)

$>$ Most rögtön indíts a szobádba rendet pakolni! (14, direkt)

$>$ Kisfiam, nem akarsz rendet rakni a szobádban? (14, indirekt)

Peti azonban nem engedelmeskedett egykönnyen. (15)

Később viszont megtanult rendet tartani maga körül. (16)

\section{Rejtett fenyegetés kategóriája:}

Pál régebben postásként dolgozott a nyugdíjazásáig. (17)

Most feleségével él egy társasház első emeletén. (17)

Sajnálatukra a szomszédban három fiatal lakik. (16) Páléknak gyakran jelent gondot a hangoskodásuk. (15)

Hetente többször is buliznak a kérések ellenére. (17)

Az egyik alkalommal Pál megelégelte a dolgot. (16)
Az éjszaka közepén átment a zajongó társasághoz. (17)

A házigazda ajtónyitásakor Pál így szólt: (14)

$>$ Ha nem hagyjátok abba a hangoskodást, rendőrt hívok! (16, direkt)

$>$ Együtt szeretnétek szórakozni, vagy a rendörökkel? (16, indirekt)

$\mathrm{Az}$ ijedt fiatalok lejjebb vették a hangerőt. (15)

A későbbiekben sokkal kevesebb gond volt velük. (15)

\section{Leplezett megvesztegetés kategóriája:}

Péter ügyvédként dolgozott egy pénzügyi vállalatnál. (16)

Egy tárgyalásra vezetett, amikor szirénázást hallott. (17)

Egy rendőrautó követte, és lehúzódásra intette öt. (18)

Péter leparkolta jármüvét a leállósávba. (15)

A rendőr odasétált Péterhez, hogy igazoltassa őt. (17)

Továbbá közölte, hogy Péter túl gyorsan hajtott. (14) A tiszt meg is kezdte a büntetőcédula megírását. (17) Péter sietett, ezért feltette a következő kérdést: (17)

> Biztos úr, nem intézhetnénk el a bírságot másként? (15, indirekt)

$>$ Biztos úr, adok ötezer forintot, ha elenged. (15, direkt)

A rendőr feljelentette őt vesztegetés gyanújával. (17) A bíróságon azonban tisztázni tudta magát. (15)

\section{Udvarias kérés kategóriája:}

Bea családja vendégül látta rokonaikat. (15)

Az előkészületeiből mindenki kivette a részét. (18)

Bea apja a kertet igyekezett széppé varázsolni. (17) Az édesanya a konyhában tevékenykedett Beával. (17)

Bea húga a vendégszobát takarította ki. (15)

Minden nagyon jól haladt a desszert elkészítéséig. (16)

Ekkor azonban kiderült, hogy nincs elég cukor. (14)

Végül így szólt Beához az elfoglalt édesanyja: (15)

$>$ Kislányom, nincs kedved elmenni a boltba cukorért? (15, indirekt)

$>$ Kislányom, légy szíves menj el a boltba cukorért! (14, direkt)

Bea természetesen teljesítette a kérést. (15)

Ennek köszönhetően az ebéd időben elkészült. (16) 